УдК 342.9

\author{
О. Ф. Кобзар
}

\title{
ЩОДО ВИЗНАЧЕННЯ ПОНЯТЬ ПУБЛІЧНОЇ БЕЗПЕКИ ТА ПОРЯДКУ
}

Постановка проблеми. Сучасні тенденції розвитку України дають можливість говорити про те, що сьогодні відбувається реформування політичних, соціальних, економічних та організаційних основ суспільного й державного життя. Ці процеси так чи інакше впливають на стан відносин у суспільстві, оскільки перехідний період завжди пов'язується з відсутністю соціальної стабільності, загостренням соціальних конфліктів і погіршенням кримінальної обстановки. За таких обставин важливого значення набуває здатність держави підтримувати публічний порядок та забезпечувати верховенство закону, що є однією з передумов зміцнення миру й злагоди. Специфіка реалізації цієї функції полягає в необхідності дотримання балансу між обов'язком держави захистити публічні інтереси та необхідністю захисту основоположних прав і свобод людини й громадянина, що визнаються найвищими соціальними цінностями. 3 огляду на норми ст. ст. 92, 116 Конституції України забезпечення публічного порядку виступає метою діяльності держави.

Однією з головних функцій держави $є$ охорона громадського порядку. Ця функція входить у коло публічних відносин, відносин між владою та громадянином. Тобто народ (громадяни) делегував певні природні функції влади державі, унаслідок чого очікує від влади забезпечення власної безпеки, зокрема безпеки, що унеможливлює будь-яке порушення прав громадян та осіб, які перебувають під захистом держави. У межах реформування системи Міністерства внутрішніх справ України 2 липня 2015 р. було прийнято Закон України «Про Національну поліцію», який набрав чинності 7 листопада 2015 р. Відповідно до ст. 2 цього закону завданням поліції є надання послуг у сфері забезпечення публічної безпеки й порядку.

Аналіз останніх досліджень і публікацій. Питання забезпечення публічної безпеки й порядку для науки адміністративного права та діяльності є новим, тоді як активно розробляються актуальні проблеми встановлення й забезпечення громадського порядку та громадської безпеки. Різні 
аспекти окресленої наукової проблеми знайшли відображення в працях В.В. Доненка, В.О. Заросила, І.В. Зозулі, М.В. Лошицького, В.В. Малікова, А.А. Манжули, Р.С. Мельника, А.М. Подоляки, О.Ю. Прокопенка та інших учених. Незважаючи на наявність наукових досліджень, пов'язаних із поняттям громадської безпеки й громадського порядку, питання публічної безпеки не вивчалося.

Метою статті є проведення дослідження теоретичних аспектів визначення понять публічної безпеки та порядку в умовах функціонування поліції в Україні.

Виклад основного матеріалу. У ст. 1 Закону України «Про Національну поліцію» зазначено, що Національна поліція України - це центральний орган виконавчої влади, який служить суспільству шляхом забезпечення охорони прав і свобод людини, протидії злочинності, підтримання публічної безпеки й порядку. У ст. 2 Закону України «Про Національну поліцію» однією з функцій поліції названо здійснення охорони та забезпечення публічної безпеки [1]. Водночас уперше в законодавчій практиці держави щодо діяльності силових і правоохоронних структур законодавцем без будь-якого попереднього обговорення з громадою та відповідного наукового обгрунтування було введено термін «публічна безпека». Такий стан справ потребує певного аналізу щодо правильності й можливості застосування згаданого терміна [2].

Сьогодні практично відсутні також наукові публікації з питань публічної безпеки. Наприклад, Д.О. Беззубов, застосовуючи термін «суспільна безпека» («безпека суспільства») фактично як похідний від поняття національної безпеки, зіставляє його як «взаємопов'язані спільні інтереси й завдання суспільної та державної систем безпеки, на рівні недержавної системи за участю громадськості й об’єднань громадян». При цьому вчений визнає наявність терміна «громадська безпека» в Конституції України, однак вважає перспективним «новий постмодерний підхід» від експертів так званих недержавних аналітичних структур [3, с. 74], що фактично зводиться до «безпечних умов життєдіяльності» суспільства та «суспільного добробуту». Д.О. Беззубов зазначає: «Слово «добробут» $€$ ключовим у визначенні на Заході змісту поняття «public security» (у перекладі з англійської - «суспільна безпека», «державна безпека», «публічна безпека»; на побутовому рівні означає підтримку порядку), під яким розуміють здійснення захисту інститутів громадянського суспільства, що передбачає протидію загрозам добробуту громадян, суспільству загалом» [3, с. 77].

Подібне розуміння поняття й відмінності публічної безпеки та публічного порядку має також Е.В. Саманюк, яка стверджує: «У літературі та чинному законодавстві досить широко використовується термін «громадський порядок» поряд із поняттями «громадська безпека», «правопорядок», «публічний порядок», які не є тотожними категоріями. Складність у розмежуванні наведених понять полягає в тому, що стан впорядкованості вольових відносин досягається під впливом цілої низки соціальних норм» [4]. 
В.Г. Фатхутдінов у процесі дослідження співвідношення понять громадського й публічного порядку в галузі правничої герменевтики зазначає, що ці лексичні одиниці утворено за однаковою словотворчою моделлю: вони походять від іменників. Тому є сенс визначити семантику слів, від яких утворились аналізовані терміни [5].

Як вказано у «Великому тлумачному словнику сучасної української мови», лексема «громада» є багатозначним словом. Основними іiі значеннями виступають такі: «1) група людей, об’єднаних спільністю становища, інтересів тощо; 2) об'єднання людей, що ставить перед собою певні спільні завдання; організація». Відповідно, «громадський» - «який відбувається в суспільстві або стосується суспільства, пов'язаний із ним; належний усій громаді, усьому суспільству, колективний; призначений для загального користування; який добровільно обслуговує різні аспекти життя колективу» [6, с. 199].

Упорядник «Нового словника іншомовних слів» стверджує, що лексема «публіка» веде походження з латини та має декілька стилістично різнорідних значень: «збірн. Люди, які перебувають де-небудь як глядачі, слухачі, відвідувачі; розм. Люди, народ, товариство; жарт., зневажл. Непевні, підозрілі люди». Відповідно, «публічний» тлумачиться таким чином: «1) який відбувається в присутності публіки, людей; прилюдний, привселюдний, гласний, відкритий; 2) призначений для широкого відвідування, користування; громадський, загальний, загальнодоступний» [7, с. 621].

Порівняльний аналіз семантики термінів свідчить про наявність певної сфери перетину значень щодо опосередкованого відношення до людей, проте терміну «публічний» не властиві семи, що вказують на суспільний характер, елементи організації спільноти.

В.Г. Фатхутдінов говорить, що поняття «публічний порядок» в адміністративному сенсі не властиве навіть на рівні слововживання на всьому пострадянському просторі. Воно застосовується лише під час здійснення компаративних юридичних досліджень, коли вивчаються специфічні явища інших правових сімей [5]. Так, I.А. Андреєва, розглядаючи особливості діяльності французької адміністративної поліції, вказує на такі ознаки публічного порядку, що виділялися законом від 5 квітня 1884 р., як спокій, безпека та санітарно-гігієнічне благополуччя. На переконання науковця, це формулювання увійшло до Основного кодексу адміністративно-територіальних утворень, а також до Кодексу внутрішньої безпеки 2012 р. Практика адміністративної юстиції додала також суспільну мораль і повагу до людської гідності особистості. Тому, як вважає I.А. Андреєва, поняття «публічний порядок» залишається підставою та мірою адміністративно-поліцейської діяльності Франції [8, с. 47].

О.С. Проневич у дослідженні ролі й місця поліції в системі органів публічної адміністрації Польщі наголошує, що публічна безпека, з одного боку, передбачає збереження порядку та суспільних цінностей, які охороняють державу й громадян перед загрозливими для правопорядку явищами, а з іншого - означає фактичний стан, що уможливлює без загрози шкоди нормальне функціонування державної організації й реалізації іiі інте- 
ресів, збереження життя, здоров'я та майна людей, а також користування правами й свободами, гарантованими конституцією та іншими правовими приписами [9, с. 743].

В. Кернз, спираючись на право Європейського Союзу, надає стислий аналіз публічного порядку та сутності його теорії. Інші науковці (наприклад, I.I. Тріска та В.В. Левицька) визначають публічний порядок як «публічно-правові відносини, що мають імперативний характер і визначають основи суспільного ладу держави». Однак поки що все це свідчить про несміливу появу нових думок у галузі становлення вітчизняного публічного права [2].

Викладене дає змогу вважати, що законодавець відсутністю роз'яснення терміна «публічна безпека» припустився грубого порушення законотворчої техніки та фактично поставив новостворену Національну поліцію України за межі конституційного поля. Однак широке сприйняття міжнародним суспільством терміна «публічна безпека» як більш пріоритетного, ніж вітчизняний «громадська безпека», вимагає від науковців і законодавця негайного повернення до цієї проблеми [2]. Зокрема, такої ж думки дотримується В.Г. Фатхутдінов, який наголошує: «Формується нагальна наукова потреба в здійсненні експертизи цього нормативного акта на предмет його загрози правовій безпеці, цілісності й системності безпекового законодавства» [10].

Однак необхідно зауважити, що однією з передумов прийняття Закону України «Про Національну поліцію» є європейська інтеграція України, яка зобов'язує поліцію слугувати суспільству шляхом забезпечення охорони прав і свобод людини, протидії злочинності, підтримання публічної безпеки й порядку. Така вимога обумовлюється Декларацією про поліцію, прийнятою Резолюцією Парламентської Асамблеї Ради Європи № 690(1979), зміст якої реалізує засади Європейської конвенції про права людини і основоположних свобод та інших національних і міжнародних документів, вважаючи необхідною основою існування мирного суспільства, яке користується перевагами порядку та публічної безпеки.

Згідно з Додатком до Рекомендації № Rec(2001)10 «Про Європейський кодекс поліцейської етики», який застосовується до традиційних публічних сил поліції чи поліцейських служб, основні цілі поліції є такими:

- підтримка публічного спокою, забезпечення права й порядку в суспільстві;

- захист і дотримання основоположних прав та свобод особи, закріплених, зокрема, у Європейській конвенції про права людини і основоположних свобод;

- запобігання й подолання злочинності;

- виявлення злочинів;

- надання допомоги та послуг суспільству.

Пункт 64 Закону Королівства Бельгії «Про діяльність поліції від 5 серпня 1992 р. визначає, що поліція є важливим інститутом демократичної держави, керованої верховенством права. Вона є найважливішим елемен- 
том системи кримінальної юстиції, органом, відповідальним за публічний порядок. Поліція наділяється особливими повноваженнями та водночас повинна бути інтегрованою в суспільство, якому вона служить, тощо.

Коментованим законом введено поняття «публічна безпека й порядок», які на законодавчому рівні, що визначає діяльність органів внутрішніх справ, не зазначалися.

Аналізуючи зміст Декларації про поліцію, прийнятої Резолюцією Парламентської Асамблеї Ради Європи № 690(1979), можна зробити висновок, що публічний порядок у цьому документі визначено як урегульований стан публічних суспільних відносин, які забезпечують належне функціонування держави, іiі структур, громадських формувань і громадян.

Висновки. Таким чином, поняття «громадський порядок», «громадська безпека та правопорядок», згідно із законом, поглинаються ширшим у своєму розумінні поняттям «публічна безпека й порядок».

Як уже зазначалося, поліція - це складова частина системи органів внутрішніх справ, які здійснюють державну виконавчу владу у внутрішній сфеpi держави. Поліцію створено державою для здійснення іï функцій щодо служіння суспільству. Відповідно до Закону України «Про центральні органи виконавчої влади» від 17 березня 2011 р. № 3166-VI національна поліція України - центральний орган виконавчої влади, який входить до системи центральних органів виконавчої влади. Вищим органом системи центральних органів виконавчої влади $є$ Кабінет Міністрів України, який спрямовує й координує діяльність поліції через міністра внутрішніх справ України.

Отже, законом на Національну поліцію України покладено завдання щодо підтримання публічної безпеки й порядку. Тому вважаємо, що поняття «підтримання публічної безпеки та порядку» має забезпечити дотримання Національною поліцією України таких конституційних понять, як «правопорядок», «громадська безпека» та «громадський порядок».

\section{Література}

1. Про Національну поліцію : Закон України від 2 липня 2015 р. № 580-VIII [Електронний pecypc]. - Режим доступу : http:/ / zakon3.rada.gov.ua/laws/show/580-19.

2. Зозуля І.В. Закон України «Про Національну поліцію»: публічна чи громадська безпека? / I.В. Зозуля, О.І. Довгань / / Форум права. - 2015. - № 5. - С. 85-92. - [Електронний ресурс]. Режим доступу : http: / / nbuv.gov.ua/UJRN/FP_index.

3. Беззубов Д.О. До поняття концепту суспільної безпеки (адміністративний аспект) / Д.О. Беззубов / / Бюлетень Міністерства юстиції України. - 2013. - № 5(139). - С. 73-79.

4. Саманюк Э.В. О соотношении понятий «общественная безопасность» и «общественный порядок» / Э.В. Саманюк / / Молодой ученый. - 2014. - № 3. - С. 671-675.

5. Фатхутдінов В.Г. Громадський vs публічний у дзеркалі правничої герменевтики / В.Г. Фатхутдінов / / Науковий вісник Херсонського державного університету. Серія «Юридичні науки». - 2015. - Вип. 4. - Т. 1. - С. 45-50.

6. Великий тлумачний словник сучасної української мови / уклад. і гол. ред. В.Т. Бусел. К. ; Ірпінь : ВТФ «Перун», 2003. - 1440 с.

7. Новий словник іншомовних слів : [20 000 слів] / уклад. і передм. О.М. Сліпушко. - К. : Аконіт, 2008. - 848 с.

8. Андреева И.А. «Административная полиция» - институт, понятие и конструкция административного права Франции / И.А. Андреева // Вестник Омского университета. Серия «Право». - 2013. - № 4(37). - С. 44-49. 
9. Проневич О.С. Роль і місце поліції в системі органів публічної адміністрації Польщі / О.С. Проневич / / Форум права. - 2010. - № 4. - С. 741-747. - [Електронний ресурс]. - Режим доступу : http://nbuv.gov.ua/UJRN/FP_index.htm_2010_4_118.

10. Фатхутдінов В.Е. Частотність операціоналізації та контекстуальність використання терміну «публічна безпека» в Законі України про «Національну поліцію України» / В.Е. Фатхутдінов [Електронний ресурс]. - Режим доступу : http://goal-int.org/chastotnist-operacionalizacii-takontekstualnist-vikoristannya-terminu-publichna-bezpeka-v-zakoni-ukraini-pro-nacionalnu-policiyuukraini/.

\section{Анот а ц і я}

Кобзар О. Ф. Щодо визначення понять публічної безпеки та порядку. - Стаття.

У статті досліджуються й конкретизуються теоретичні погляди на визначення понять громадської безпеки та порядку в контексті діяльності Національної поліції України. У результаті проведеного аналізу встановлено, що ці поняття є новими для українського законодавства. Зазначено, що поняття «громадський порядок і громадська безпека» поглинається більш широким у своєму розумінні поняттям «публічна безпека та порядок».

Ключові слова: публічна безпека, публічний порядок, поліція, громадський порядок.

\section{А н н о т а ци я}

Кобзар А. Ф. Об определении понятия публичной безопасности и порядка. - Статья.

В статье исследуются и конкретизируются теоретические взгляды на определение понятий публичной безопасности и порядка в контексте деятельности Национальной полиции Украины. В результате проведенного анализа установлено, что данные понятия являются новыми для украинского законодательства. Указано, что понятие «общественный порядок и общественная безопасность» поглощается более широким в своем понимании понятием «публичная безопасность и порядок».

Ключевые слова: публичная безопасность, общественный порядок, полиция, общественный порядок.

\section{S u m m a r y}

Kobzar A. F. Determination of the concept of public security and order. - Article.

The article examines theoretical views and specified in the definition of public security and order of concepts in the context of the National Police of Ukraine activity. The analysis found that these concepts are new to the Ukrainian legislation. It is indicated that the notion of "public order and public security" absorbed broader in their understanding of the concept of "public security and order".

Key words: public safety, public order, police and public order. 